\title{
Mine Dewatering Water reuse in Large Scale Thermal Power Plant
}

\author{
Yanning $\mathrm{Gao}^{\mathrm{a}}$, Kecheng Liu, Wenlong Hou \\ Hebei Electric Power Research Institute, Hebei Shijiazhuang 050021, China \\ ahbdyygyn@163.com
}

Keywords: dewatering water, reuse, advanced treatment, thermal power plant.

\begin{abstract}
The articletaking actual project as an example, introduces the design and operation of the system of coal mine drainage reuse in the large-scale thermal power plant. Operation data shows that mine drainage water treatment system is stable in operation, the effluent quality can meet the power plant auxiliary engine circulating water system, desulfurization system, the boiler feed water and other water requirements.
\end{abstract}

\section{Introduction}

Mine dewatering water mainly contains the rain, surface water, groundwater, karst water and living water and various water along the original and new cracks penetrate underground mining space, which was due to the mining process destroyed the original occurrence state of groundwater and caused a rift, the aquifers contact more close[1]. In the mining process, drainage water are often mixed with sand particles of mud, dust, soluble salts, acids and bases, coal particles, grease and other pollutants. Therefore, the drainage water treatment process has the extremely important influence for dewatering economic benefits and environmental benefits of water resources [2].

Table 1 The characteristic of mine dewatering water.

\begin{tabular}{ccc|ccc}
\hline Parameter & Unit & Value & Parameter & Unit & Value \\
$\mathrm{pH}$ & & 8.2 & $\mathrm{~K}^{+}$ & $\mathrm{mg} / \mathrm{L}$ & 2.7 \\
Total hardness & $\mathrm{mg} / \mathrm{L}$ & 214.2 & Soloble $\mathrm{Fe}$ & $\mathrm{mg} / \mathrm{L}$ & 0.164 \\
$\mathrm{Ca}^{2+}$ & $\mathrm{mg} / \mathrm{L}$ & 49.7 & $\mathrm{SS}$ & $\mathrm{mg} / \mathrm{L}$ & 233 \\
$\mathrm{Mg}^{2+}$ & $\mathrm{mg} / \mathrm{L}$ & 21.9 & $\mathrm{HCO}^{-}$ & $\mathrm{mg} / \mathrm{L}$ & 336.8 \\
$\mathrm{Cl}^{-}$ & $\mathrm{mg} / \mathrm{L}$ & 42.5 & $\mathrm{Na}^{+}$ & $\mathrm{mg} / \mathrm{L}$ & 123.5 \\
$\mathrm{SO}_{4}^{2-}$ & $\mathrm{mg} / \mathrm{L}$ & 151.5 & $\mathrm{Si}$ & $\mathrm{mg} / \mathrm{L}$ & 1.034 \\
$\mathrm{COD}_{\mathrm{Cr}}$ & $\mathrm{mg} / \mathrm{L}$ & 0.9 & $\mathrm{Ba}$ & $\mathrm{mg} / \mathrm{L}$ & 0.005 \\
\hline
\end{tabular}

A Power Generation Co., Ltd. using underground gushing water as the main water source of the power plant, the mine drainage dry water station underground gushing water as an alternative water source, the drainage water quality as shown in Table 1. According to the needs of different water drainage with high content of suspended solids in water quality characteristics and auxiliary power plant circulating water and boiler feed water system, the treatment are respectively arranged sparsely dry water pretreatment system and sparse dry water depth processing system. Among them, the coagulation, sedimentation and filtration are main process of sparse dry water pretreatment system, the treated effluent turbidity was less than $3 \mathrm{NTU}$, the effluent added directly to the auxiliary circulating water system, desulfurization system; and the main process of sparse dry water depth processing system containing UF, RO and EDI further treat thiseffluent for boiler feed water.

\section{The system of dewatering pretreatment}

The drainage water first flow into the pretreatment system, the system adopts mixed condensation precipitation filtration clarification process. Pretreatment system design output $400 \mathrm{t} / \mathrm{h}$, the effluent turbidity is less than 3NTU. The effluent directly into the water tank, in order to supply water for circulating water, chemical plant water and the whole plant service water. Pretreatment system 
mainly consists of in-line mixer, star flocculation equipment, $\mathrm{V}$-shaped precipitation equipment and the general fast filter.

The straight type mixer parameters are $600 * 3000 \mathrm{~mm}$, the material is 304 stainless steel. Star flocculation pool in flocculation pool, perpendicular to the flow direction of the settings tab, to produce high-frequency vortex flow, and produce dense alum. Mixing flocculation sedimentation tank sludge using gravity bucket mud, each root mud pipe end design manual butterfly valve and electric butterfly valve. Ordinary rapid filter main body of single-cell: $5000 * 4000 * 4000 \mathrm{~mm}$, filter material used in particle size of 0.5 to $1.2 \mathrm{~mm}$ quartz sand, $700 \mathrm{~mm}$ in thickness; cushion adopts particle diameter of $2 \sim 4 \mathrm{~mm}$ quartz sand, the thickness was $200 \mathrm{~mm}$. There are three conventional rapid filter backwash water pump, the pump discharge pressure $510 \mathrm{~m}^{3} / \mathrm{h}, 0.15 \mathrm{MPa}$. Pre processing outdoor setting two adjacent mud pools, pond is provided with a raw water pump house and sludge dewatering.

The coagulant was polymeric aluminum with $5 \%$ - $10 \%$ concentration, chemical dosing control between $30 \sim 40 \mathrm{mg} / \mathrm{L}$; consider the subsequent ultrafiltration reverse osmosis system, theconcentration of coagulant polyacrylamide (PAM) control in $1 \mathrm{mg} / \mathrm{L}$. Pretreatment system of effluent turbidity less than 3 NTU, the effluent of the system directly add auxiliary circulating water system, desulfurization system; after further treatment it flow into boiler feed water.

\section{The system of dewatering depth treatment}

Drainage water depth processing system is the process of membrane which main use ultrafiltration, reverse osmosis, EDI, and avoid the acid-base use and waste emissions, conforms to the requirement of the current environmental protection. The process of the system: pretreatment effluent $\rightarrow$ raw water tank $\rightarrow$ self-cleaning filter $\rightarrow$ ultra filter $\rightarrow$ ultrafiltration water tank $\rightarrow$ a booster pump $\rightarrow$ security filter $\rightarrow$ high-pressure pump $\rightarrow \mathrm{RO} \rightarrow$ carbon dioxide device $\rightarrow$ middle water pool $\rightarrow$ secondary booster pump $\rightarrow$ secondary RO $\rightarrow$ RO water tank $\rightarrow$ EDI water supply pump $\rightarrow$ EDI $\rightarrow$ desalting water tank $\rightarrow$ saline water pump. The main processing equipment of water depth treatment system is introduced as follows:

\subsection{Self-cleaning filter}

Two self-cleaning filters are provided before the filter, the output of each filter is $150 \mathrm{~m}^{3} / \mathrm{h}$. Self-cleaning filter has a control panel configuration, according to the import and export pressure differential and cumulative time automatic control of filter backwashing process and backwashing the filter effluent, do not set externally pressurized water and air assisted backwashing. The minimum working pressure of the filter is $0.15 \mathrm{MPa}$; the maximum working pressure is $1.0 \mathrm{MPa}$.

\subsection{Ultrafiltration}

The ultrafiltration system of this project is composed of 2 sets of ultrafiltration machine, the design of the net output is $2 * 93 \mathrm{~m}^{3} / \mathrm{h}$. Ultrafiltration device adopts the Koch company production of the ultrafiltration membrane component, the inner pressure filtration, each host has 22 ultrafiltration membrane module. Membrane material was PES, the effective area of each root membrane module for $80.9 \mathrm{~m}^{2}$, the system running flux is $55 \mathrm{~L} / \mathrm{m}^{2} \cdot \mathrm{h}$. The effluent of design system for the turbidity $<0.2 \mathrm{NTU}, \mathrm{SDI}<3.0$, water recycling rate is more than or equal to $90 \%$, filtration cycle is more than or equal to 30 minutes, backwashing and total duration 1.5 minutes. Table 2 was some operating parameters of ultrafiltration device. The Table 2 shows that the effluent of the ultrafiltration device was stable, the water yield was below 0.1NTU, and the water producing SDI was below 1, which can meet the requirement of the water inlet of the reverse osmosis device.

Table 2 The operating parameters of ultrafiltration device

\begin{tabular}{cccc}
\hline Date & Influent pressure (MPa) & Effluentturbidity (NTU) & Effluent SDI \\
\hline April 14th & 0.11 & 0.055 & 0.66 \\
May 22th & 0.13 & 0.049 & 0.71 \\
June 19th & 0.12 & 0.046 & 0.67 \\
August 17th & 0.12 & 0.053 & 0.67 \\
\hline
\end{tabular}




\subsection{RO system}

The RO device adopts two stage design, the main technical parameters are shown in Table 3.

Table 3 The characteristic of RO.

\begin{tabular}{ccc}
\hline Parameter & First stage RO & Second stage RO \\
\hline Set amount & 2 sets & 2 sets \\
Out put & $70 \mathrm{~m}^{3} / \mathrm{h} / \mathrm{set}$ & $63 \mathrm{~m}^{3} / \mathrm{h} / \mathrm{set}$ \\
Order & $12: 6 / \mathrm{set}$ & $5: 3 / \mathrm{set}$ \\
Wavecyber & $300 \mathrm{p}-6$ & $300 \mathrm{p}-6$ \\
Module & $\mathrm{BW} 30-365 \mathrm{FR}$ & XLE-440 \\
Module amount & 216 & 96 \\
Recovery & $75 \%$ & $90 \%$ \\
Total deaaninate rate & $\geq 97 \%$ & $\geq 90 \%$ \\
\hline
\end{tabular}

The design of first stage RO device was include adding acid, adding scale inhibitor and reducing agent in the water inlet. The acid adjusted to ensure entrance water $\mathrm{pH}$ value below 7.6, which meet the requirements of the LSI value, and prevent carbonate fouling. Scale inhibitor using inhibitor MSI300, the dosage was $3.0 \sim 6.0 \mathrm{ppm}$, to prevent membrane concentration of water side slightly soluble salts, especially silica fouling. The reducing agent $\mathrm{NaHSO}_{3}$ was control ORP value less than $200 \mathrm{mV}$. Table 4 is some data of the first stage RO device operating parameters, it can be seen from Table 4 that the first stage of RO desalination rate remained at about $99 \%$. Because $\mathrm{CO}_{2}$ is very easy to penetrate the membrane, make the fresh water conductivity increases [3], there was a set of carbon removal after the first RO, in order to reduce the carbon dioxide content in the two RO water.

Table 4 The operation offirst stage RO.

\begin{tabular}{ccccc}
\hline Date & $\begin{array}{c}\text { Influent pressure } \\
(\mathrm{MPa})\end{array}$ & $\begin{array}{c}\text { Influent } \\
\text { conductivity } \\
(\mu \mathrm{s} / \mathrm{cm})\end{array}$ & $\begin{array}{c}\text { Effluent } \\
\text { conductivity } \\
(\mu \mathrm{s} / \mathrm{cm})\end{array}$ & $\begin{array}{c}\text { Desalination } \\
\text { rate } \\
(\%)\end{array}$ \\
\hline April 14th & 0.97 & 1044 & 7.23 & 99.28 \\
May 22th & 0.96 & 1108 & 8.93 & 99.19 \\
June 19th & 1.03 & 1077 & 9.44 & 99.12 \\
August 17th & 0.94 & 1129 & 10.12 & 99.10 \\
\hline
\end{tabular}

Two $\mathrm{RO}$ desalination rate is affected by $\mathrm{pH}$ value. The $\mathrm{pH}$ value of the first stage $\mathrm{RO}$ water production was $5.6 \sim 6.4$, so it should adjust $\mathrm{pH}$ value between $7.5 \sim 8.3$ by $\mathrm{NaOH}$, which could transform the residual $\mathrm{CO}_{2}$ in the water into $\mathrm{HCO}_{3}{ }^{-}$and was removed, at the same time, it can also guarantee the $\mathrm{pH}>6$ of water production to meet the requirement of EDI. The running situation of the two stage RO is shown in Table 5. It can be seen from the table that the system was stable and conductivity of the effluent can be kept below $2 \mu \mathrm{S} / \mathrm{cm}$.

Table 5 The operation of second stage RO.

\begin{tabular}{cccc}
\hline Date & $\begin{array}{c}\text { Influent } \\
\text { pressure } \\
(\mathrm{MPa})\end{array}$ & $\begin{array}{c}\text { Influent } \\
\text { conductivity } \\
(\mu \mathrm{s} / \mathrm{cm})\end{array}$ & $\begin{array}{c}\text { Effluent } \\
\text { conductivity } \\
(\mu \mathrm{s} / \mathrm{cm})\end{array}$ \\
\hline April 14th & 0.75 & 7.23 & 0.45 \\
May 22th & 0.75 & 8.93 & 0.67 \\
June 19th & 0.76 & 9.44 & 0.61 \\
August 17th & 0.75 & 10.12 & 0.79 \\
\hline
\end{tabular}




\subsection{EDI device}

EDI is a kind new membrane separation technology which combinesthe electrodialysis and ion exchange method.The structures is similar to electrodialysis, the difference is in the freshwater chamber filled with anion exchange resin. In high pure water, the conductivity of ion exchange resin is 2 to 3 orders of magnitude higher than that of the water, so almost all of the ion transfer from the solution to the lipid surface is done through the resin. The ions in water first adsorption on the resin particles by exchange, then under the action of electric field, constructed by the resin particles "ion channel" migrate to the membrane surface and through the ion selective membrane into the concentrated water chamber. At the interface of the resin, the membrane and the aqueous phase, the polarization in the interfacial diffusion makes the hydrolysis of $\mathrm{H}+$ and $\mathrm{OH}-$. Some of them take part in the load current, most of them would regenerate the resin,this associatethe ion exchange, ion transport, electricity regeneration together and can achieve continuous deionization objective [4].

The system hastwo sets of EDI device (the Electropure EXL-700 module), single module output $6.33 \mathrm{~m}^{3} / \mathrm{h}$, each can run separately, and can also be run together.The main technical parameters of EDI device is shown in Table 6. Discharge regulating valves are arranged on the water pipe, the concentrated water discharge pipe and the water discharge pipe of the EDI device, the water yield and the recovery rate of the control device are adjusted by adjusting the opening degree of the three valves.

Table 6 The characteristics of EDI.

\begin{tabular}{cc}
\hline Parameter & Value \\
\hline Design voltage & $450 \sim 500 \mathrm{VDC}$ \\
Work voltage & $100 \sim 300 \mathrm{VDC}$ \\
Design current & $45 \mathrm{~A}(5 \mathrm{~A} /$ module $)$ \\
Work current & $18 \mathrm{~A}(0.5 \sim 2 \mathrm{~A} /$ module $)$ \\
Effluent flux & $57 \mathrm{~m}^{3} / \mathrm{h}$ \\
Influent temperature & $5 \sim 35^{\circ} \mathrm{C}$ \\
Effluent resistivity & $\geq 10 \mathrm{M}$ \\
Recovery & $\geq 90 \%$ \\
$\mathrm{SiO}_{2}$ & $\leq 0.02 \mathrm{mg} / \mathrm{L}$ \\
\hline
\end{tabular}

EDI device needs to regenerate before it works. During the regeneration process the system work normally according to the program, and transferred the state to the voltage regulator module, until the water discharge satisfied the quality. In the process of system operation, the water flow rate is $1.4 \mathrm{~m}^{3} / \mathrm{h}$, the water production flow rate is $63 \mathrm{~m}^{3} / \mathrm{h}$, the discharge rate of concentrated water is determined according to the recovery rate. The actual operation of the EDI device is shown in Table 7.

Tbale 7 The operation data of EDI.

\begin{tabular}{ccc|ccc}
\hline Parameter & Unit & Value & Parameter & Unit & Value \\
\hline Influent conductivity & $\mu \mathrm{S} / \mathrm{cm}$ & 0.547 & $\mathrm{SiO}_{2}$ & $\mu \mathrm{g} / \mathrm{L}$ & 2.8 \\
Effluent conductivity & $\mu \mathrm{S} / \mathrm{cm}$ & 0.06 & Recovery & $\%$ & 95 \\
Concentrate conductivity & $\mu \mathrm{S} / \mathrm{cm}$ & 96.3 & Influent pressure & $\mathrm{MPa}$ & 0.32 \\
Effluent flux & $\mathrm{m}^{3} / \mathrm{h}$ & 55 & Effluent pressure & $\mathrm{MPa}$ & 0.1 \\
Concentrate flux & $\mathrm{m}^{3} / \mathrm{h}$ & 4.5 & & & \\
\hline
\end{tabular}

\section{Conclusion}

(1) The power operation results show that when the influent water quality meet the design requirements, the mine drainage water after treatment as the source of production fully able to meet the requirements of the water quality in the power plant. 
(2) The water quality can meet the requirements of the boiler water using full membrane method for the water depth treatment and it has advantages of low operating cost, simple operation, no acid and alkali emissions, economic and environmental friendliness.

(3) When thetreated mine drainage water used as industrial water, it can save a lot of groundwater resources, at the same time it has significant economic and social benefits.

\section{References}

[1] Wang Tianping, XieJiancang, Zhang Jianlong, etc..Based on catastrophe theory of Xi Wang village mine drain dry water development and utilization of risk assessment [J]. Xi'an University of technology, 2010 (4): 417-423.

[2] JiaZhenzhe, Li Dongyang. Study on complex water treatment technology in open coal mine [J]. Openmining technology, 2012(3):42-46.

[3] Zhou Baiqing, Chen Zhihe. Thermal power plant water treatment [M]. Beijing: China Electric Power Press, 2009:175 176.

[4] Zhao Yi, Wang Na, Sun Xiaojun, et al. Application of electric ion (EDI) technology in the production of high purity water [J]. Journal of North China Electric Power University, 2007, 34 (3): $72-76$. 